\title{
Effect of Physicochemical Pretreatments and Enzymatic Hydrolysis on Corn Straw Degradation and Reducing Sugar Yield
}

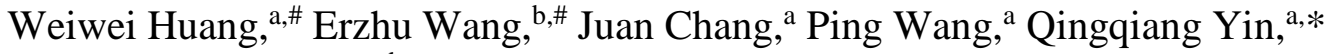 \\ Chaoqi Liu, ${ }^{a}$ Qun Zhu, ${ }^{b}$ and Fushan Lu ${ }^{\mathrm{c}}$
}

\begin{abstract}
Straw lignocelluloses were converted to reducing sugar for possible use for bioenergy production via physicochemical pretreatments and enzymatic hydrolysis. The experiment was divided into 2 steps. The first step focused on breaking the crystal structure and removing lignin in corn straw. The lignin, hemicellulose, and cellulose degradation rates observed were $92.2 \%, 73.7 \%$, and $4.6 \%$, respectively, after corn straw was treated with sodium hydroxide $(3 \% \mathrm{w} / \mathrm{w})$ plus high-pressure steam (autoclave), $74.8 \%, 72.5 \%$, and $4.3 \%$ after corn straw was treated with sodium hydroxide $(8 \%, \mathrm{w} / \mathrm{w})$ plus wet steam explosion, compared with native corn straw $(P<0.05)$. The second step was enzymatic hydrolysis for the pretreated straw. The enzymatic hydrolysis could yield $576 \mathrm{mg} / \mathrm{g}$ reducing sugar and significantly degrade cellulose and hemicellulose contents by $93.3 \%$ and $94.4 \%$ for the corn straw pretreated with sodium hydroxide plus high-pressure steam. For the corn straw pretreated with sodium hydroxide plus wet steam explosion, the enzymatic hydrolysis could yield $508 \mathrm{mg} / \mathrm{g}$ reducing sugar, and degrade cellulose and hemicellulose contents by $83.5 \%$ and $84.2 \%$, respectively, compared with the untreated corn straw $(P<0.05)$. Scanning electron microscopy showed that the physicochemical pretreatments plus enzymatic hydrolysis degraded corn straw to many small molecules. Thus, physicochemical pretreatments plus enzymatic hydrolysis converted lignocellulose to reducing sugar effectively.
\end{abstract}

Keywords: Corn straw; Physicochemical pretreatment; Enzymatic hydrolysis; Reducing sugar yield; Ultramicroscopic structure

Contact information: a: College of Animal Science and Veterinary Medicine, Henan Agricultural University, Zhengzhou 450002 China; b: Henan Delin Biological Product Co. Ltd., Xinxiang 453000 China; c: Henan Engineering and Technology Research Center of Feed Microbes, Zhoukou 466000 China; ${ }^{\#}$ Both authors contribute equally; *Corresponding author: qqy1964@126.com

\section{INTRODUCTION}

Corn straw is one of the most abundant agricultural residues in the world, and it represents an ideally cheap, renewable, and widely available feedstock for bioconversion to fuels and chemicals (Sánchez and Cardona 2008). However, most corn straw is burned or buried in the fields as waste due to the shortage of effective treatment methods (Jiang et al. 2012). Crop straw is mainly composed of cellulose, hemicellulose, and lignin, which can be converted to reducing sugar and other low-molecular weight carbohydrates for biofuel and other high-value biomaterial products (Lambert et al. 1990; Himmel et al. 2007; Kumar et al. 2009). Nevertheless, the crystal structure of straw inhibits enzyme accessibility and hydrolysis for reducing sugar. Lignin is a macromolecule and a highly 
branched polymer, which forms the lignin sheath and surrounds hemicellulose and cellulose to protect them from degradation by cellulase and hemicellulase (Bellido et al. 2014; Wang et al. 2015a; Zhang et al. 2015). Therefore, lignin removal from straw is one of the most important steps for thorough degradation. Of course, the synchronous degradation of lignin, cellulose, and hemicellulose increases the effectiveness of enzymatic hydrolysis for reducing sugar. To solve this problem, many pretreatment methods such as physical, chemical, and physicochemical treatments have been applied (Chang et al. 2012; Kim and Han 2012; Joe et al. 2015; Qin et al. 2015).

It is extremely difficult to achieve good results by adopting a single method. In recent studies, two or three methods have been combined together for processing different crop straws to achieve the desired effects (Sun and Cheng 2002; Singh et al. 2014; Singh et al. 2015; Wang et al. 2015b). Steam explosion and high-pressure steam (autoclave) are the more effective pretreatment methods for crop straw degradation because they have the more potential for energy efficiency, lower environmental impact, and more soluble carbohydrate production than other pretreatment technologies (Liu et al. 1999; Viola et al. 2008; Alvira et al. 2010). Even so, steam explosion and highpressure steam are not able to increase lignin degradation to a high level (Liu et al. 1999; Chang et al. 2012). Hence, sodium hydroxide $(\mathrm{NaOH})$ is used together with steam explosion or high-pressure steam in this study to degrade crop straw completely. Biological treatments of crop straw including microbial fermentation and enzymatic hydrolysis are safe, environmentally friendly, and less energy intensive than other methods (Dinis et al. 2009). However, they are restricted by the pretreatment methods, enzyme activity, enzyme price, microbial species, hydrolysis reaction effectiveness, microbial fermenting period, etc.; great improvement is needed for commercial applications (Sun and Cheng 2002).

Physical treatment is more effective than typical chemical approaches in breaking up the straw crystal structure (Chang et al. 2012). Chemical treatment can degrade lignin effectively (Kim and Han 2012), while microbial fermentation and enzymatic hydrolysis are more effective to convert straw to reducing sugar and low-molecular weight carbohydrates effectively based on the physicochemical pretreatments (Chang et al. 2012; Wang 2015c). In order to increase crop straw application, physicochemical pretreatments and enzymatic hydrolysis were combined together in this study to provide new alternative methods for converting crop straw to reducing sugar effectively.

\section{EXPERIMENTAL}

\section{Materials Preparation}

The air-dried corn straw was ground in a FW 100 hammer crusher (Beijing Junhao Technological Development Co., Ltd, Beijing, China), passed through a 40-mesh screen, and stored at room temperature before use. The corn straw was pretreated with QBS-80B steam explosion machine (Hebi Zhengdao Biological Energy Co., Ltd, Hebi, China) and LDZX-30KBS high-pressure steam sterilization pot(Shanghai Shenan Medical Apparatus Factory, Shanghai, China), respectively. The combination of cellulase and hemicellulase was purchased from Shandong Zesheng Biological Technology Co. Ltd., Taian, China. The activities of cellulase and hemicellulase were determined as 323 FPU/g (142 mg protein/g) and $3069 \mathrm{U} / \mathrm{g}$ (4 mg protein/g) according to the NREL Laboratory Analytical Procedure (IUPAC 1987). The liquid cellulase and hemicellulase 
solution was prepared as follows: A certain quantity of enzyme powder was weighed, placed in distilled saline at ratio of 1:10 (enzyme power: saline), shaken at 200 RPM for $3 \mathrm{~h}$, filtrated with filter paper, and passed through a $0.25 \mu \mathrm{m}$ filter membrane. Cellulase and hemicellulase activities were determined as $32 \mathrm{FPU} / \mathrm{mL}$ and $307 \mathrm{U} / \mathrm{mL}$ under the conditions of $\mathrm{pH} 4.8$ and $40{ }^{\circ} \mathrm{C}$.

\section{Straw Pretreatments}

According to a previous study (Wang 2015c), a three-factor and three-level orthogonal experiment $(\mathrm{NaOH}$ concentrations $(\mathrm{w} / \mathrm{w}): 2.0 \%, 2.5 \%, 3.0 \%$; solid-liquid ratios: 1:6.0, 1:7.5, 1:9.0 (w:v); autoclave time: $15 \mathrm{~min}, 30 \mathrm{~min}, 45 \mathrm{~min})$ was conducted to determine the optimal conditions for removing lignin in corn straw. The amount of $\mathrm{NaOH}$ was weighed according to corn straw weight $(\mathrm{w} / \mathrm{w})$ and dissolved in water at the corresponding solid-liquid ratios (corn straw:water, w/v). Corn straw was soaked in $\mathrm{NaOH}$ solution in a flask and autoclaved at $121{ }^{\circ} \mathrm{C}$ for the corresponding time. After cooling to room temperature, the $\mathrm{pH}$ was adjusted to 7.0 with $9 \mathrm{M}$ hydrochloric acid, and the material was dried at $65^{\circ} \mathrm{C}$. There were three replicates for each treatment condition in the experiment.

For the pretreatment of $\mathrm{NaOH}$-wet steam explosion, $0 \%, 2 \%, 4 \%, 6 \%$, and $8 \%$ $\mathrm{NaOH}$ was weighed according to the weight of corn straw and dissolved in water at the ratio of 1:2 (i.e., corn straw:water $=1: 2, \mathrm{w} / \mathrm{v}$ ). The $\mathrm{NaOH}$ solution was sprayed evenly on corn straw, which was placed in a steam chamber. The steam pressure was adjusted to 2.5 $\mathrm{MPa}$, kept for $200 \mathrm{~s}$, and then suddenly released at the end of the treatment to give the explosion effect. The exploded samples were collected and dried at $65{ }^{\circ} \mathrm{C}$. The pretreatment of $\mathrm{NaOH}$-dry steam explosion was prepared according to the above protocol modified by evenly spraying the different proportions of solid $\mathrm{NaOH}$ without dissolution in water on corn straw respectively.

\section{The Optimal Conditions of Enzymatic Hydrolysis}

The corn straw pretreated with $\mathrm{NaOH}$ plus autoclave was used as the substrate (50 $\mathrm{g} / \mathrm{L})$ under the condition of 200 RPM. A four-factor and four-level orthogonal experiment (enzyme activity (cellulase activity: 6.45, 12.90, 19.35, $25.80 \mathrm{FPU} / \mathrm{g}$ biomass plus hemicellulase activity: $61.88,123.76,185.64,247.52 \mathrm{U} / \mathrm{g}$ biomass); $\mathrm{pH}$ : 4.2, 4.8, 5.4, 6.0; reaction time: $24 \mathrm{~h}, 48 \mathrm{~h}, 72 \mathrm{~h}, 96 \mathrm{~h}$; reaction temperature: $30,40,50,60{ }^{\circ} \mathrm{C}$ ) was used to optimize the enzymatic hydrolysis conditions. The $0.1 \mathrm{M}$ citric acid-sodium citrate buffers of $\mathrm{pH} 4.2,4.8,5.4$, and 6.0 were used to make the different enzyme solutions with $\mathrm{pH}$ values of 4.2, 4.8, 5.4, and 6.0. The reaction $\mathrm{pH}$ values were adjusted to 4.2, 4.8, 5.4, and 6.0 with $9 \mathrm{M}$ hydrochloric acid. The ratio of liquid and corn straw in the reaction volume was adjusted to $20: 1(\mathrm{v} / \mathrm{w})$ with the different $\mathrm{pH}$ buffers of citric acid-sodium citrate. The enzymatic reaction was terminated by placing the flask in boiling water for 15 min with stirring. The mixture was then cooled to room temperature with cold water.

\section{Enzymatic Hydrolysis of the Different Pretreated Corn Straw}

The condition and process of enzymatic hydrolysis were conducted according to results obtained from the above experiment, i.e., $\mathrm{pH} 4.8$, cellulase activity $25.8 \mathrm{FPU} / \mathrm{mL}$, hemicellulase activity $247.5 \mathrm{U} / \mathrm{mL}, 40{ }^{\circ} \mathrm{C}$, and $96 \mathrm{~h}$ reaction in shaking incubator at 200 RPM. Total reducing sugar in the reaction liquid was estimated by the dinitrosalicylic acid (DNS) method (Miller 1959), and then the $\mathrm{pH}$ was adjusted to 7.0 with 5\% potassium hydroxide (w/v). The biomass after enzymatic hydrolysis was dried at $65{ }^{\circ} \mathrm{C}$ to 
$90 \%$ dry matter, which was ground for further analysis. The cellulose, hemicellulose, and lignin fractions in the samples were determined according to the method of Van Soest et al. (1991). The experimental design is listed in Table 1.

Table 1. The Different Physicochemical Pretreatments of Corn Straw for Enzymatic Hydrolysis

\section{Groups Different Physicochemical Treatments}

$1 \quad$ Control group (untreated corn straw)

$2 \mathrm{NaOH}(3 \%, \mathrm{w} / \mathrm{w})+$ autoclave (straw: $\mathrm{NaOH}$ solution $=1: 9, \mathrm{w} / \mathrm{v}$ )

3 Dry steam explosion without water addition

$4 \quad \mathrm{NaOH}(4 \%, \mathrm{w} / \mathrm{w})+$ dry steam explosion

$5 \quad \mathrm{NaOH}(8 \%, \mathrm{w} / \mathrm{w})+$ dry steam explosion

$6 \quad$ Wet steam explosion (straw:water $=1: 2, \mathrm{w} / \mathrm{v}$ )

$7 \quad \mathrm{NaOH}(4 \%, \mathrm{w} / \mathrm{w})+$ wet steam explosion (straw:NaOH solution $=1: 2, \mathrm{w} / \mathrm{v}$ )

$8 \mathrm{NaOH}(8 \%, \mathrm{w} / \mathrm{w})+$ wet steam explosion (straw: $\mathrm{NaOH}$ solution $=1: 2, \mathrm{w} / \mathrm{v})$

\section{Surface Morphology of the Treated Corn Straw}

Physical changes in the native and treated corn straw were analyzed by scanning electron microscopy (SEM). The SEM images were taken at 1000× magnification using an S-3400NIISEM instrument (Hitachi Co. Ltd., Tokyo, Japan) at acceleration voltages of $10 \mathrm{kV}$. All samples were mounted on conductive adhesive tape and coated with goldpalladium (SC7640, Quorum Technology, Newhaven, UK).

\section{Statistical Analysis}

The data were expressed as mean \pm standard errors (SE) for calculating chemical compositions and reducing sugar yield of the pretreated corn straw with different physicochemical methods plus enzymatic hydrolysis. The data were determined for each of the three replicates per treatment, which was averaged to give a single value of each sample for subsequent statistical analysis. The data were analyzed using the ANOVA in SPSS 20.0 software (IBM, Armonk, NY, USA). Tukey's multiple range test was employed to evaluate the differences. Differences were considered statistically significant at $\mathrm{P}<0.05$.

\section{RESULTS AND DISCUSSION}

\section{Optimal Conditions of $\mathrm{NaOH}-A u t o c l a v e$ Pretreatment for Lignin Removal in Corn Straw}

The orthogonal experiment in Table 2 indicated that the optimal conditions of $\mathrm{NaOH}$-autoclave pretreatment were as follows: $3 \%(\mathrm{w} / \mathrm{v}) \mathrm{NaOH}$, solid-liquid ratio at 1:9 (w:v), autoclaved at $121{ }^{\circ} \mathrm{C}$ for $15 \mathrm{~min}$. The impact order was: $\mathrm{NaOH}$ concentration > solid-liquid ratio > autoclaving time. The minimal lignin content was $0.61 \%$ in group 9 $(\mathrm{P}<0.05)$. The lignin content in $\mathrm{NaOH}$-autoclave treated corn straw was further reduced to $0.50 \%$ (lignin degradation rate was $92.21 \%$ ) under the above optimal conditions, in which hemicellulose and cellulose degradation rates were $73.21 \%$ and $4.6 \%$, respectively, 
compared with the native corn straw $(\mathrm{P}<0.05)$ (Table 3$)$. There are few reports about $\mathrm{NaOH}$-autoclave pretreatment of crop straw. Previous research showed that acid-sprayed or acid-soaked barley straw with $1.0 \% \mathrm{H}_{2} \mathrm{SO}_{4}(\mathrm{w} / \mathrm{w})$ was kept at $220{ }^{\circ} \mathrm{C}$ for 5 min to result in a high glucose yield with enzymatic hydrolysis (Linde et al. 2006). Whether the alkali or acid pretreatment is conducted, the main function of alkali or acid plus highpressure steam was to destroy straw crystal structure for the further enzymatic hydrolysis.

Table 2. The Orthogonal Design of $\mathrm{NaOH}$-Autoclave Pretreatments for Lignin Removal in Corn Straw

\begin{tabular}{|c|c|c|c|c|}
\hline Groups & $\begin{array}{c}\mathrm{NaOH} \\
\text { Concentrations (\%) } \\
\text { Factor A }\end{array}$ & $\begin{array}{c}\text { Solid-liquid } \\
\text { Ratio }(\mathrm{g} / \mathrm{mL}) \\
\text { Factor B }\end{array}$ & $\begin{array}{c}\text { Autoclaving Time } \\
\text { (min) } \\
\text { Factor C }\end{array}$ & $\begin{array}{l}\text { Lignin Contents } \\
\text { (\%) }\end{array}$ \\
\hline 1 & 2.0 & $1: 6.0$ & 15 & $3.87 \pm 0.008^{A}$ \\
\hline 2 & 2.0 & $1: 7.5$ & 30 & $3.73 \pm 0.050^{A}$ \\
\hline 3 & 2.0 & $1: 9.0$ & 45 & $2.41 \pm 0.076^{\mathrm{B}}$ \\
\hline 4 & 2.5 & $1: 6.0$ & 30 & $2.37 \pm 0.140^{\mathrm{B}}$ \\
\hline 5 & 2.5 & $1: 7.5$ & 45 & $1.75 \pm 0.120^{C}$ \\
\hline 6 & 2.5 & $1: 9.0$ & 15 & $0.68 \pm 0.019 \mathrm{~F}$ \\
\hline 7 & 3.0 & $1: 6.0$ & 45 & $1.38 \pm 0.013^{\mathrm{D}}$ \\
\hline 8 & 3.0 & $1: 7.5$ & 15 & $0.90 \pm 0.067^{E}$ \\
\hline 9 & 3.0 & $1: 9.0$ & 30 & $0.61 \pm 0.029 \mathrm{~F}$ \\
\hline K1 & 10.01 & 7.62 & 5.45 & \\
\hline K2 & 4.80 & 6.38 & 6.71 & \\
\hline K3 & 2.89 & 3.70 & 5.54 & \\
\hline $\mathrm{k} 1$ & 3.34 & 2.54 & 1.82 & \\
\hline $\mathrm{k} 2$ & 1.60 & 2.13 & 2.24 & \\
\hline k3 & 0.96 & 1.23 & 1.85 & \\
\hline $\mathrm{R}$ & 2.38 & 1.31 & 0.42 & \\
\hline $\begin{array}{c}\text { Important } \\
\text { Order }\end{array}$ & \multicolumn{3}{|c|}{$\mathrm{R}_{\mathrm{A}}>\mathrm{R}_{\mathrm{B}}>\mathrm{R}_{\mathrm{C}}$} & \\
\hline $\begin{array}{l}\text { Optimal } \\
\text { Levels }\end{array}$ & 3.0 & $1: 9.0$ & 15 & \\
\hline
\end{tabular}

Note: The data followed by the different capital letters in the same column are significantly different from each other $(P<0.05)$, while the data followed by the same capital letters in the same column are insignificantly different from each other $(P>0.05)$.

\section{Effect of Different Physicochemical Treatments on Lignocellulose Degradation of Corn Straw}

Table 3indicated that steam explosion could significantly increase cellulose, hemicellulose, and lignin degradation rates of corn straw $(\mathrm{P}<0.05)$. $\mathrm{NaOH}$ addition during the dry steam explosion increased cellulose and hemicellulose degradation $(\mathrm{P}<$ $0.05)$, but did not have any effect on lignin degradation $(\mathrm{P}>0.05)$. However, $\mathrm{NaOH}$ addition during the wet steam explosion significantly increased the degradation of lignin $(\mathrm{P}<0.05)$ but not cellulose or hemicellulose $(\mathrm{P}>0.05)$. The maximal lignin degradation rate was $74.8 \%$ in the treated corn straw with $8 \% \mathrm{NaOH}$-wet steam explosion, in which hemicellulose and cellulose degradation rates were $72.5 \%$ and $4.3 \%$, respectively, compared with the native corn straw $(\mathrm{P}<0.05)$. The function of $\mathrm{NaOH}$ is to permeate into the interface between lignin and hemicellulose under the help of high pressure and water to cause lignin degradation (Li et al. 2007); therefore, alkali solution treatment has more effect on lignin degradation than cellulose and hemicellulose degradation. 
According to this result, $\mathrm{NaOH}$ concentrations of $4 \%$ and $8 \%(\mathrm{w} / \mathrm{w})$ were selected for further studies.

Physicochemical pretreatments are effective in degrading the crystal structure of straw prior to microbial fermentation and enzymatic hydrolysis (Viola et al. 2008; Alvira et al. 2010; Chang et al. 2012; Toquero and Bolado 2014), but it has some limits for high lignin degradation. It was reported that lignin degradation rate of rice straw are $52.6 \%$ under the conditions of $2.96 \% \mathrm{NaOH}, 81.8{ }^{\circ} \mathrm{C}$, and 56.7 min reaction, with a glucose yield of $254 \mathrm{~g} / \mathrm{kg}$ after enzymatic hydrolysis (Kim and Han 2012). Another study showed that the lignin degradation rate of corn straw was $77.9 \%$ in an alkaline reaction $(1.5 \%$ $\mathrm{NaOH}, 100{ }^{\circ} \mathrm{C}, 1.5 \mathrm{~h}$ ) followed by steam explosion (Guo et al. 2013).

The previous results indicate that alkaline hydrolysis requires high temperature and a long reaction time, which can degrade lignin to some extent. This study combines the physical and chemical reactions together to save time and increase lignin degradation effectively. The combined treatments of $\mathrm{NaOH}(3 \%)$ plus autoclave or $\mathrm{NaOH}(8 \%)$ plus wet steam explosion significantly decreased lignin content by $92.2 \%(6.42 \% \mathrm{vs} .0 .5 \%)$ or $74.8 \%$ (6.42\% vs. $1.62 \%$ ), respectively, indicating superiority of the combined treatments together. It is emphasized that $\mathrm{NaOH}$-wet steam explosion is very useful and economical for straw pretreatment due to saving time(200 s)and making later dry processing easy(i.e., corn straw: water $=1: 2, \mathrm{w} / \mathrm{v})$. Even so, the combined treatments have no significant effect on cellulose degradation, which will require the further enzymatic hydrolysis.

Table 3. Effect of Different Pretreatments on the Main Compositions of Corn Straw (\%)

\begin{tabular}{|c|c|c|c|}
\hline $\mathrm{NaOH}$ levels & Hemicellulose & Cellulose & Lignin \\
\hline $\begin{array}{c}\text { Control } \\
\mathrm{NaOH}+\text { Dry Steam } \\
\text { Explosion }\end{array}$ & $30.85 \pm 1.12^{\mathrm{A}}$ & $37.38 \pm 0.93^{\mathrm{A}}$ & $6.42 \pm 0.16^{\mathrm{A}}$ \\
\hline 0 & & & \\
\hline 2 & $8.33 \pm 0.76^{\mathrm{B}}$ & $35.85 \pm 0.30^{\mathrm{B}}$ & $5.51 \pm 0.12^{\mathrm{B}}$ \\
\hline 4 & $5.39 \pm 0.52^{\mathrm{D}}$ & $35.97 \pm 0.45^{\mathrm{B}}$ & $5.69 \pm 0.16^{\mathrm{B}}$ \\
\hline 6 & $5.24 \pm 0.61^{\mathrm{D}}$ & $34.26 \pm 0.26^{\mathrm{C}}$ & $5.12 \pm 0.26^{\mathrm{B}}$ \\
\hline 8 & $6.82 \pm 0.22^{\mathrm{C}}$ & $31.66 \pm 0.22^{\mathrm{D}}$ & $5.44 \pm 0.26^{\mathrm{B}}$ \\
\hline $\begin{array}{c}\mathrm{NaOH}+\text { Wet Steam } \\
\text { Explosion }\end{array}$ & $5.90 \pm 0.49^{\mathrm{CD}}$ & $29.50 \pm 1.31^{\mathrm{E}}$ & $5.35 \pm 0.22^{\mathrm{B}}$ \\
\hline 0 & & & \\
\hline 2 & $7.18 \pm 0.16^{\mathrm{C}}$ & $36.80 \pm 0.16^{\mathrm{AB}}$ & $5.39 \pm 0.38^{\mathrm{B}}$ \\
\hline 4 & $8.44 \pm 0.43^{\mathrm{B}}$ & $36.87 \pm 1.18^{\mathrm{AB}}$ & $5.49 \pm 0.07^{\mathrm{B}}$ \\
\hline 6 & $8.37 \pm 0.15^{\mathrm{B}}$ & $36.89 \pm 0.40^{\mathrm{AB}}$ & $4.11 \pm 0.20^{\mathrm{C}}$ \\
\hline 8 & $8.45 \pm 0.28^{\mathrm{B}}$ & $35.67 \pm 1.47^{\mathrm{B}}$ & $2.92 \pm 0.09^{\mathrm{D}}$ \\
\hline $\mathrm{NaOH}+$ Autoclave & $8.49 \pm 0.10^{\mathrm{B}}$ & $35.78 \pm 1.66^{\mathrm{B}}$ & $1.62 \pm 0.19^{\mathrm{E}}$ \\
\hline
\end{tabular}

Note: Data followed by different capital letters in the same columns are significantly different from each other $(P<0.05)$, while the data followed by the same capital letters in the same columns are insignificantly different from each other $(P>0.05)$.

\section{Optimal Conditions of Enzymatic Hydrolysis for the Corn Straw Pretreated with $\mathrm{NaOH}$ plus Autoclave}

The orthogonal experiment in Table 4 showed that the optimal conditions of enzymatic hydrolysis were as follows: cellulase activity, 25.80 FPU/g; hemicellulase activity, $248 \mathrm{U} / \mathrm{g}$; $\mathrm{pH}$ 4.8; substrate concentration, $50 \mathrm{~g} / \mathrm{L}$; reaction time, $96 \mathrm{~h}$; and temperature, $40{ }^{\circ} \mathrm{C}$. The impact order was: $\mathrm{pH}>$ temperature $>$ enzyme activity > 
enzymatic reaction time. Under the above optimal conditions of enzymatic hydrolysis, the maximal reducing sugar yield was $575.5 \mathrm{mg} / \mathrm{g}$ biomass $(\mathrm{P}<0.05)$. According to the principle of enzymatic reaction kinetics, when the substrate concentration is fixed, the catalytic reaction rate increases with increasing enzyme dosage (Liao et al. 2008), which increases the cost of bioconversion. Therefore, selecting the appropriate enzyme dosage for converting cellulose materials economically and effectively is very important. This study provides a better alternative method than the previous studies for straw degradation and reducing sugar yield (Yu et al. 2009; Kim and Han 2012; Wang et al. 2015b).

Table 4. Optimal Conditions of Enzymatic Hydrolysis for the Corn Straw Pretreated with $\mathrm{NaOH}$ plus Autoclave

\begin{tabular}{|c|c|c|c|c|c|}
\hline \multirow[t]{2}{*}{ Groups } & $\begin{array}{c}\text { Enzyme } \\
\text { Dosage }^{*} \\
(\mathrm{FPU} / \mathrm{g}+\mathrm{U} / \mathrm{g})\end{array}$ & $\mathrm{pH}$ & $\begin{array}{l}\text { Reaction } \\
\text { Time (h) }\end{array}$ & $\begin{array}{l}\text { Temperature } \\
\left({ }^{\circ} \mathrm{C}\right)\end{array}$ & \multirow[t]{2}{*}{$\begin{array}{c}\text { Reducing Sugar } \\
\text { Yield } \\
(\mathrm{mg} / \mathrm{g})\end{array}$} \\
\hline & Factor A & Factor B & Factor C & Factor D & \\
\hline 1 & $6.45+61.8$ & 4.2 & 24 & 30 & $208.18 \pm 0.70^{\mathrm{H}}$ \\
\hline 2 & $6.45+61.8$ & 4.8 & 48 & 40 & $385.91 \pm 6.04^{\mathrm{E}}$ \\
\hline 3 & $6.45+61.8$ & 5.4 & 72 & 50 & $164.34 \pm 2.25^{J}$ \\
\hline 4 & $6.45+61.8$ & 6.0 & 96 & 60 & $75.57 \pm 2.37^{L}$ \\
\hline 5 & $12.90+123.76$ & 4.2 & 48 & 50 & $483.78 \pm 2.25^{\mathrm{B}}$ \\
\hline 6 & $12.90+123.76$ & 4.8 & 24 & 60 & $209.34 \pm 1.86^{\mathrm{H}}$ \\
\hline 7 & $12.90+123.76$ & 5.4 & 96 & 30 & $135.82 \pm 6.27^{K}$ \\
\hline 8 & $12.90+123.76$ & 6.0 & 72 & 40 & $181.06 \pm 6.27^{\mid}$ \\
\hline 9 & $19.35+185.64$ & 4.2 & 72 & 60 & $289.27 \pm 6.43^{F}$ \\
\hline 10 & $19.35+185.64$ & 4.8 & 96 & 50 & $571.57 \pm 1.86^{A}$ \\
\hline 11 & $19.35+185.64$ & 5.4 & 24 & 40 & $406.81 \pm 0.85^{\mathrm{D}}$ \\
\hline 12 & $19.35+185.64$ & 6.0 & 48 & 30 & $154.75 \pm 5.54^{\mathrm{J}}$ \\
\hline 13 & $25.80+247.52$ & 4.2 & 96 & 40 & $567.39 \pm 14.61^{\mathrm{A}}$ \\
\hline 14 & $25.80+247.52$ & 4.8 & 72 & 30 & $448.86 \pm 21.03^{C}$ \\
\hline 15 & $25.80+247.52$ & 5.4 & 48 & 60 & $183.77 \pm 9.98^{\prime}$ \\
\hline 16 & $25.80+247.52$ & 6.0 & 24 & 50 & $250.05 \pm 4.06^{\mathrm{G}}$ \\
\hline $\mathrm{K} 1$ & 834.00 & 1548.62 & 1074.38 & 947.61 & \\
\hline $\mathrm{K} 2$ & 1010.00 & 1615.68 & 1208.21 & 1541.17 & \\
\hline K3 & 1422.40 & 890.74 & 1083.53 & 1469.74 & \\
\hline $\mathrm{K} 4$ & 1450.07 & 661.43 & 1350.35 & 757.95 & \\
\hline $\mathrm{k} 1$ & 208.50 & 387.16 & 268.60 & 236.90 & \\
\hline k2 & 252.50 & 403.92 & 302.05 & 385.29 & \\
\hline k3 & 355.60 & 222.68 & 270.88 & 367.44 & \\
\hline k4 & 362.52 & 165.36 & 337.59 & 189.49 & \\
\hline $\mathrm{R}$ & 154.02 & 238.56 & 68.99 & 195.80 & \\
\hline $\begin{array}{l}\text { Important } \\
\text { Order }\end{array}$ & \multicolumn{4}{|c|}{$R_{B}>R_{D}>R_{A}>R_{C}$} & \\
\hline $\begin{array}{l}\text { Optimal } \\
\text { Levels }\end{array}$ & 25.80 & 4.8 & 96 & 40 & \\
\hline
\end{tabular}

${ }^{*}$ Enzyme dosage includes cellulase (CFU / g) and hemicellulase $(\mathrm{U} / \mathrm{g})$. The data followed by the different capital letters in the same column are significantly different from each other $(P<0.05)$, while the data followed by the same capital letters in the same column are insignificantly different from each other $(P>0.05)$. 


\section{The Effect of Different Pretreatments plus Enzymatic Hydrolysis on Chemical Compositions of Corn Straw and Reducing Sugar Yield}

The contents of cellulose, hemicellulose, and lignin in the corn straw pretreated with physicochemical methods plus enzymatic hydrolysis are shown in Table 5, and the corresponding reducing sugar yields are shown in Table 6. Enzymatic hydrolysis significantly decreased cellulose and hemicellulose contents in corn straw $(\mathrm{P}<0.05)$, without any effect on lignin degradation $(P>0.05)$. One explanation is that enzyme powder contains only cellulase and hemicellulase but not ligninase. After enzymatic hydrolysis, the degradation rates of cellulose and hemicellulose were increased by $93.3 \%$ and $94.4 \%$, respectively, and reducing sugar yield was $575.5 \mathrm{mg} / \mathrm{g}$ biomass in the corn straw pretreated with $\mathrm{NaOH}(3 \%)$ plus autoclave $(\mathrm{P}<0.05) ; 83.5 \%, 84.2 \%$, and $508.2 \mathrm{mg} / \mathrm{g}$ in the corn straw pretreated with $\mathrm{NaOH}(8 \%)$ plus steam explosion $(\mathrm{P}<0.05)$; $21.9 \%, 11.5 \%$, and $249.3 \mathrm{mg} / \mathrm{g}$ in the native corn straw $(\mathrm{P}<0.05)$. This result indicated that physicochemical pretreatment significantly increased reducing sugar yield, as noted previously (Ko et al. 2009; Carrasco et al. 2011; Kim and Han 2012). The reasons are that the pretreatments provide more chances or accessibility for enzymatic hydrolyzation (Kim and Holtzapple 2005; Mosier et al. 2005; Hendriks and Zeeman 2009; HolopainenMantila et al. 2013), as well as increase hydrophilic straw surface to promote the interaction between enzyme and straw (Yun 2014). The higher yield of reducing sugar from the pretreated corn straw indicates the effectiveness of these kinds of pretreatments in this study.

\section{Surface Morphology and SEM}

The surface morphology and SEM images indicated that the surface of the untreated corn straw was unbroken (Fig. 1); however, the treated corn straw showed that all the methods could break up the smooth surface of native straw (Figs. 2 to Fig. 5).

$\mathrm{NaOH}$-autoclave and $\mathrm{NaOH}$-wet explosion were effective in breaking up corn straw, in which the straw surface was rougher and covered with a destroyed wax layer, and the size of corn straw tended to be smaller. After enzymatic hydrolysis, the pretreated straw turned into powder or many smaller molecules, indicating that the optimal physicochemical pretreatments followed by enzymatic hydrolysis are more effective in altering the structure of corn straw than the single pretreatments.

The physicochemical pretreatments formed many craters by silica dissolution, exposed the composition of fiber bundle, which made the enzymatic hydrolysis more efficient ( $\mathrm{Li}$ et al. 2007), in agreement with this study. Generally, lignin and hemicellulose encase cellulose, which prevents cellulase from reaching cellulose fibrils. Previous studies showed that lignin appeared on the outer surface of straw after explosion to expose more internal cellulose surfaces for enzyme accessibility (Selig et al. 2007; Kristensen et al. 2008).

Other reports indicated that the lignin layer of the exploded corn straw was easily removed because lignin was less strongly bound to carbohydrate polymers (Liu et al. 1999; Chang et al. 2012), especially when $\mathrm{NaOH}$ was combined with physical pretreatment together to increase the lignin removal and enhance cellulose digestibility. Cellulose and hemicellulose accessibility was improved by creating pores and breaking the lignin-carbohydrate complex (Mooney et al. 1998). Therefore, it is convenient for enzymes to attack the cellulose and hemicellulose fractions effectively, which was demonstrated by higher reducing sugar yield under the condition that lignin in corn straw is removed by $\mathrm{NaOH}$-autoclave or $\mathrm{NaOH}$-wet explosion pretreatments in this study. 
Table 5. Main Compositions of the Different Chemically Treated Corn Straw With or Without Enzymatic Hydrolysis (\%, dry matter)

\begin{tabular}{|c|c|c|c|c|c|c|c|c|}
\hline Group & & Cellulose & & & $\begin{array}{l}\text { Hemi- } \\
\text { Cellulose }\end{array}$ & & Lignin & \\
\hline & Y1 & Y2 & Y3 & $\mathrm{Y} 1$ & Y2 & Y3 & $\mathrm{Y} 1$ & Y2 \\
\hline 1 & $\begin{array}{l}37.60 \pm \\
1.01^{\mathrm{Aa}} \\
\end{array}$ & $\begin{array}{l}29.36 \pm \\
0.62^{\mathrm{Ab}} \\
\end{array}$ & 21.91 & $\begin{array}{l}30.13 \pm \\
1.43^{\mathrm{Aa}} \\
\end{array}$ & $\begin{array}{l}26.67 \pm \\
0.41^{\mathrm{Ab}} \\
\end{array}$ & 11.48 & $\begin{array}{l}5.96 \pm \\
0.70^{\mathrm{Aa}} \\
\end{array}$ & $\begin{array}{l}6.26 \pm \\
0.54^{\mathrm{Aa}}\end{array}$ \\
\hline 2 & $\begin{array}{c}33.26 \pm \\
1.50^{\mathrm{Ca}} \\
\end{array}$ & $\begin{array}{l}2.22 \pm \\
0.22^{\mathrm{Gb}} \\
\end{array}$ & 93.33 & $\begin{array}{l}7.65 \pm \\
0.59 \mathrm{Ba} \\
\end{array}$ & $\begin{array}{l}0.43 \pm \\
0.03^{\mathrm{Eb}} \\
\end{array}$ & 94.38 & $\begin{array}{l}0.59 \pm \\
0.08^{\mathrm{Da}}\end{array}$ & $\begin{array}{l}0.58 \pm \\
0.06^{\mathrm{Da}} \\
\end{array}$ \\
\hline 3 & $\begin{array}{l}34.45 \pm \\
0.74^{\mathrm{BCa}} \\
\end{array}$ & $\begin{array}{l}12.87 \pm \\
0.35^{\mathrm{Cb}} \\
\end{array}$ & 62.64 & $\begin{array}{l}7.74 \pm \\
0.59^{\mathrm{Ba}} \\
\end{array}$ & $\begin{array}{c}3.80 \pm \\
0.43^{\mathrm{BCb}} \\
\end{array}$ & 50.90 & $\begin{array}{c}5.42 \pm \\
0.07^{\mathrm{ABa}} \\
\end{array}$ & $\begin{array}{c}5.44 \pm \\
0.36^{\mathrm{ABa}} \\
\end{array}$ \\
\hline 4 & $\begin{array}{c}33.19 \pm \\
0.41^{\mathrm{Ca}}\end{array}$ & $\begin{array}{l}10.28 \pm \\
0.73^{\mathrm{Db}}\end{array}$ & 69.03 & $\begin{array}{l}5.84 \pm \\
0.26^{\mathrm{Ca}}\end{array}$ & $\begin{array}{l}4.09 \pm \\
0.26^{\mathrm{Bb}}\end{array}$ & 29.97 & $\begin{array}{c}5.58 \pm \\
0.48^{\mathrm{ABa}}\end{array}$ & $\begin{array}{c}5.21 \pm \\
0.13^{\mathrm{ABa}}\end{array}$ \\
\hline 5 & $\begin{array}{c}29.04 \pm \\
1.62^{\mathrm{Da}}\end{array}$ & $\begin{array}{l}7.39 \pm \\
0.71^{\mathrm{Eb}}\end{array}$ & 74.55 & $\begin{array}{l}5.68 \pm \\
0.15^{\mathrm{Ca}}\end{array}$ & $\begin{array}{l}3.01 \pm \\
0.36^{\mathrm{Cb}}\end{array}$ & 47.01 & $\begin{array}{c}5.50 \pm \\
0.11^{\mathrm{ABa}}\end{array}$ & $\begin{array}{c}5.11 \pm \\
0.05^{\mathrm{ABa}}\end{array}$ \\
\hline 6 & $\begin{array}{c}35.63 \pm \\
0.43^{\mathrm{Ba}} \\
\end{array}$ & $\begin{array}{l}15.35 \pm \\
1.11^{\mathrm{Bb}} \\
\end{array}$ & 56.92 & $\begin{array}{l}7.45 \pm \\
0.54^{\mathrm{Ba}} \\
\end{array}$ & $\begin{array}{c}3.58 \pm \\
0.34^{\mathrm{BCb}} \\
\end{array}$ & 51.95 & $\begin{array}{c}5.59 \pm \\
0.28^{\mathrm{ABa}} \\
\end{array}$ & $\begin{array}{c}5.38 \pm \\
0.17^{\mathrm{ABa}} \\
\end{array}$ \\
\hline 7 & $\begin{array}{c}5.79 \pm \\
0.57^{\mathrm{Ba}} \\
\end{array}$ & $\begin{array}{l}11.59 \pm \\
1.09^{\mathrm{CDb}} \\
\end{array}$ & 67.62 & $\begin{array}{l}8.23 \pm \\
0.16^{\mathrm{Ba}} \\
\end{array}$ & $\begin{array}{l}3.09 \pm \\
0.27^{\mathrm{Cb}} \\
\end{array}$ & 62.45 & $\begin{array}{l}4.49 \pm \\
0.16^{\mathrm{Ba}} \\
\end{array}$ & $\begin{array}{l}4.57 \pm \\
0.87 \mathrm{Ba} \\
\end{array}$ \\
\hline 8 & $\begin{array}{c}33.67 \pm \\
1.14^{\mathrm{Ca}}\end{array}$ & $\begin{array}{l}5.56 \pm \\
0.50^{\mathrm{Fb}}\end{array}$ & 83.49 & $\begin{array}{l}8.19 \pm \\
0.45^{\mathrm{Ba}}\end{array}$ & $\begin{array}{l}1.29 \pm \\
0.22^{\mathrm{Db}}\end{array}$ & 84.25 & $\begin{array}{l}1.60 \pm \\
0.22^{\mathrm{Ca}}\end{array}$ & $\begin{array}{l}1.50 \pm \\
0.43^{\mathrm{Ca}}\end{array}$ \\
\hline
\end{tabular}

Note: The corn straw pretreatment design in group 1-8 is listed in Table 1.Y1, lignocellulose contents after physicochemical treatments; Y2, lignocellulose contents after physicochemical treatments plus enzymatic hydrolysis; Y3, degradation rates of lignocellulose after enzymatic hydrolysis. The data followed by the different capital letters in the same columns are significantly different from each other $(P<0.05)$, while the data followed by the same capital letters in the same columns are insignificantly different from each other $(P>0.05)$. The data followed by the different lowercase letters between the two rows of pre-enzymatic hydrolysis and post-enzymatic hydrolysis are significantly different from each other $(P<0.05)$, while the data followed by the same lowercase letters between the two rows of pre-enzymatic hydrolysis and post-enzymatic hydrolysis are insignificantly different from each other ( $P>0.05)$.

Table 6. Effect of Enzymatic Hydrolysis on Reducing Sugar Yield (mg / g biomass)

\begin{tabular}{|c|c|c|}
\hline Groups & Before Enzymatic Hydrolysis & After Enzymatic Hydrolysis \\
\hline 1 & $92.63 \pm 0.18^{\mathrm{Ab}}$ & $249.33 \pm 16.99^{\mathrm{Ea}}$ \\
\hline 2 & $11.99 \pm 0.53^{\mathrm{Eb}}$ & $575.51 \pm 7.04^{\mathrm{Aa}}$ \\
\hline 3 & $47.30 \pm 0.94^{\mathrm{Bb}}$ & $360.39 \pm 7.80^{\mathrm{Da}}$ \\
\hline 4 & $27.15 \pm 2.02^{\mathrm{Db}}$ & $374.22 \pm 22.11^{\mathrm{Da}}$ \\
\hline 5 & $13.54 \pm 0.35^{\mathrm{Eb}}$ & $356.95 \pm 1.62^{\mathrm{Da}}$ \\
\hline 6 & $91.69 \pm 5.82^{\mathrm{Ab}}$ & $389.23 \pm 4.36^{\mathrm{Da}}$ \\
\hline 7 & $38.38 \pm 3.04^{\mathrm{Cb}}$ & $451.75 \pm 20.46^{\mathrm{Ca}}$ \\
\hline 8 & $11.41 \pm 1.11^{\mathrm{Eb}}$ & $508.17 \pm 9.54^{\mathrm{Ba}}$ \\
\hline
\end{tabular}

Note: The corn straw pretreatment design in group 1-8 is listed in Table 1.The data followed by the different capital letters in the same columns are significantly different from each other $(P<$ $0.05)$, while the data followed by the same capital letters in the same columns are insignificantly different from each other ( $P>0.05$ ). The data followed by the different lower-case letters in the same rows are significantly different from each other $(P<0.05)$, while the data followed by the same lower-case letters in the same rows are insignificantly different from each other $(P>0.05)$. 


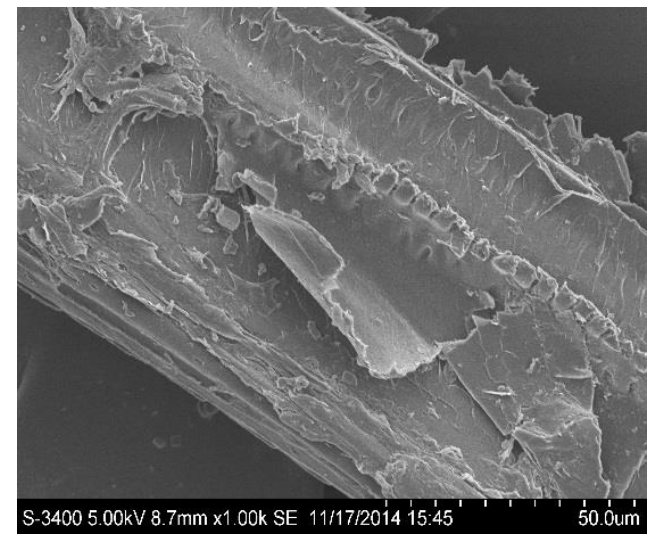

Fig. 1. Native corn straw

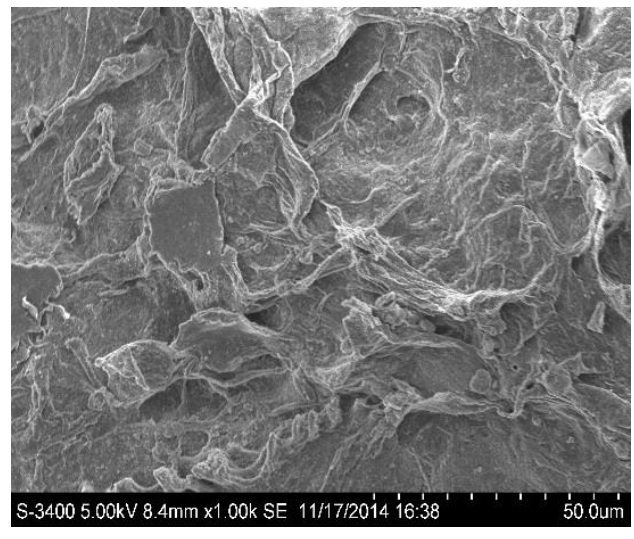

Fig. 2. Corn straw treated with sodium hydroxide (3\%) + autoclave

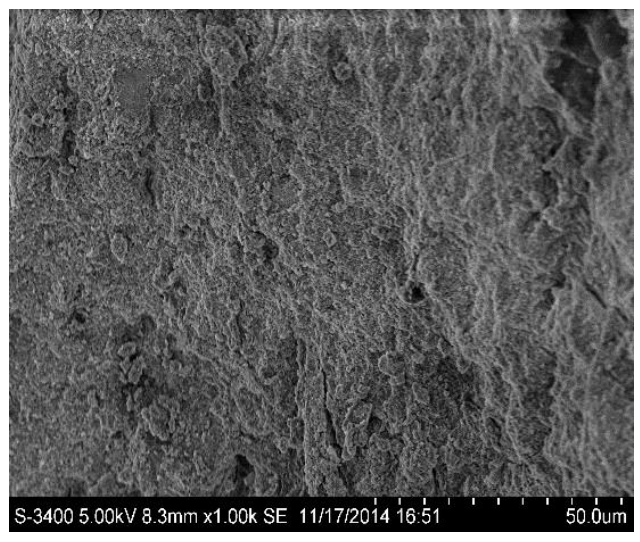

Fig. 4. Corn straw treated with sodium hydroxide (3\%) + autoclave plus enzymatic hydrolysis

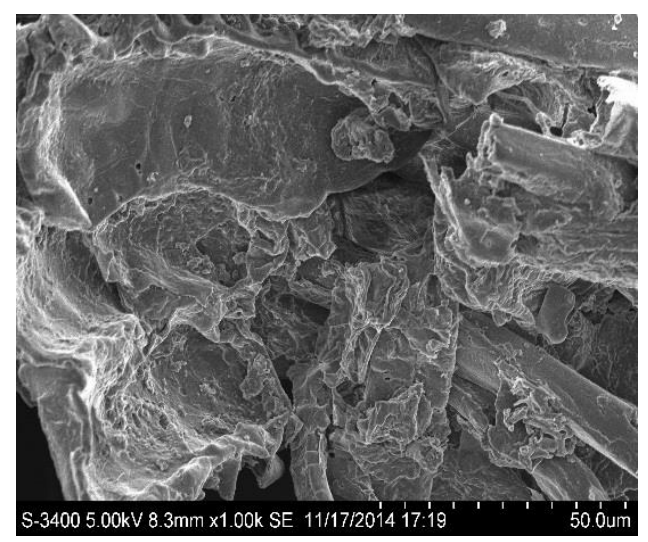

Fig. 3. Corn straw treated with sodium hydroxide $(8 \%)+$ wet steam explosion

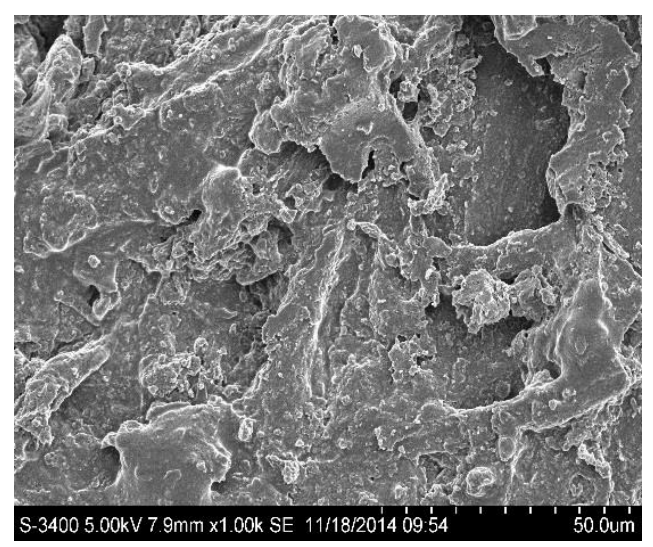

Fig. 5. Corn straw treated with sodium explosion $(8 \%)+$ wet steam explosion plus enzymatic hydrolysis 


\section{CONCLUSIONS}

1. The physicochemical pretreatments evaluated in this work were able to degrade hemicellulose and lignin in corn straw and provide more chances for accessibility and hydrolysis of enzymes.

2. These experiments showed that cellulase and hemicellulase could significantly convert cellulose and hemicellulose to reducing sugar for bioenergy and other biomaterial production based on the effective pretreatments.

\section{ACKNOWLEDGMENTS}

This research was financially supported by the China Spark Program (2015GA750012), Henan Production-Study-Research Cooperation Program (162107000069), and the National Science Foundation of China (U1204325).

\section{REFERENCES CITED}

Alvira, P., Tomas-pejo, E., Ballesteros, M., and Negro, M. J. (2010). "Pretreatment technologies for an efficient bioethanol production process based on enzymatic hydrolysis: A review," Bioresour. Technol. 101, 4851-4861. DOI: 10.1016/j.biortech.2009.11.093

Bellido, C., Loureiro Pinto, M., Coca, M., Gonzalez-Benito, M., and Garcia-Cubero, M. T. (2014). "Acetone-butanol-ethanol (ABE) production by Clostridium beijerinckii from wheat straw hydrolysates: Efficient use of penta and hexa carbohydrates,"Bioresour. Technol. 167, 198-205. DOI: 10.1016/j.biortech.2014.06.020

Carrasco, C., Baudel, H., Peñarrieta, M., Solano, C., Tejeda, L., Roslander, C., Galbe, M., and Lidén, G. (2011). "Steam pretreatment and fermentation of the straw material "Paja Brava" using simultaneous saccharification and co-fermentation," J. Biosci. Bioeng. 111, 167-174. DOI: 10.1016/j.jbiosc.2010.10.009

Chang, J., Cheng, W., Yin, Q. Q., Zuo, R. Y., Song, A. D., Zheng, Q. H., Wang, P., Wang, X., and Liu, J. X. (2012). "Effect of steam explosion and microbial fermentation on cellulose and lignin degradation of corn stover,"Bioresour. Technol. 104, 587-592. DOI: 10.1016/j.biortech.2011.10.070

Dinis, M. J., Bezerra, R. M. F., Nunes, F., Dias, A. A., Guedes, C. V., Ferreira, L. M. M., Cone, J. W., Marques, G. S. M., Barros, A. R. N., and Rodrigues, M. A. M. (2009). "Modification of wheat straw lignin by solid fermentation with white-rot fungi," Bioresour. Technol. 100, 4829-4835. DOI: 10.1016/j.biortech.2009.04.036

Guo, H. W., Chang, J., Yin, Q. Q., Wang, P., Lu, M., Wang, X., and Dang, X. W. (2013). "Effect of the combined physical and chemical treatments with microbial fermentation on corn straw degradation," Bioresour. Technol. 148, 361-365. DOI: 10.1016/j.biortech.2013.09.001

Hendriks, A. T., and Zeeman, G. (2009). "Pretreatments to enhance the digestibility of lignocellulosic biomass," Bioresour. Technol. 100, 10-18. DOI: 10.1016/j.biortech.2008.05.027 
Himmel, M. E., Ding, S. Y., Johnson, D. K., Adney, W. S., Nimlos, M. R., Brady, J. W., and Foust, T. D. (2007). "Biomass recalcitrance: Engineering plants and enzymes for biofuels production," Science 315, 804-807. DOI: 10.1126/science.1137016

Holopainen-Mantila, U., Marjamaa, K., Merali, Z., Käsper, A., Bot, P., Jääskeläinen, A. S., Waldron, K., Kruus, K., and Tamminen, T. (2013). "Impact of hydrothermal pretreatment to chemical composition, enzymatic digestibility and spatial distribution of cell wall polymers," Bioresour. Technol. 138, 156-162. DOI:

10.1016/j.biortech.2013.03.152

International Union of Pure and Applied Chemistry (IUPAC) (1987). "Measurement of cellulase activities," Pure Appl. Chem. 59, 257-268.

Jiang, D., Zhuang, D., Fu, J. Y., Huang, Y. H., and Wen, K. G. (2012). "Bioenergy potential from crop residues in China: availability and distribution," Renew. Sustain. Energ. Rev. 16, 1377-1382. DOI: 10.016/j.rser.2011.12.012

Joe, M. H., Kim, J. Y., Lim, S. Y., Kim, D. H., Bai, S., Park, H., Lee, S. G., Han, S. J., and Choi, J. I. (2015). "Microalgal lipid production using the hydrolysates of rice straw pretreated with gamma irradiation and alkali solution," Biotechnol. Biofuels. 8, 125. DOI: $10.1186 / \mathrm{s} 13068-015-0308-\mathrm{x}$

Kim, I., and Han, J. I. (2012). "Optimization of alkaline pretreatment conditions for enhancing reducing sugar yield of rice straw by response surface methodology," Biomass Bioenerg. 46, 210-217. DOI: 10.1016/j.biombioe.2012.08.024

Kim, S., and Holtzapple, M.T. (2005). "Lime pretreatment and enzymatic hydrolysis of corn stover,” Bioresour. Technol. 96, 1994-2006. DOI: 10.1016/j.biortech.2005.01.014

Ko, J. K., Bak, J. S., Jung, M. W., Lee, H. J., Choi, I. G., Kim, T. H., and Kim, K. H. (2009). "Ethanol production from rice straw using optimized aqueous-ammonia soaking pretreatment and simultaneous saccharification and fermentation processes," Bioresour. Technol. 100, 4374-4380. DOI: 10.1016/j.biortech.2009.04.026

Kristensen, J.B., Thygesen, L.G., Felby, C., Jørgensen, H., and Elder, T. (2008). "Cellwallstructural changes in wheat straw pretreated for bioethanol production," Biotechnol. Biofuels 1, 1-5.DOI: 10.1186/1754-6834-1-5

Kumar, P., Barrett, D. M., Delwiche, M. J., and Stroeve, P. (2009). "Methods for pretreatment of lignocellulosic biomass for efficient hydrolysis and biofuel production," J. Ind. Eng. Chem. Res. 48, 3713-3729. DOI: 10.1021/ie801542g

Lambert, R. O., Moore-Bulls, J. M. R., and Barrier, J. W. (1990). "An evaluation of two acid hydrolysis processes for the conversion of cellulosic feedstocks to ethanol and other chemicals," Appl. Biochem. Biotechnol. 25, 773-783. DOI: 10.1007/BF02920294

Li, J. B., Henriksson, G., and Gellerstedt, G. (2007). "Lignin depolymerization/ repolymerization and its critical role for delignification of aspen wood by steam explosion," Bioresour. Technol. 98, 3061-3068. DOI: 10.1016/j.biortech.2006.10.018

Liao, W., Liu, Y., Wen, Z. Y., Frear, C., and Chen, S. L. (2008). "Kinetic modeling of enzymatic hydrolysis of cellulose in differently pretreated fibers from dairy manure," Biotechnol. Bioeng. 101, 441-451. DOI: 10.1002/bit.21921

Linde, M., Galbe, M., and Zacchi, G. (2006). "Steam pretreatment of acid-sprayed and acid-soaked barley straw for production of ethanol," Appl. Biochem. Biotechnol. 129132, 546-562.

Liu, J. X., Orskov, E. R., and Chen, X. B. (1999). "Optimization of steam treatment as a method for upgrading rice straw as feeds," Anim. Feed Sci. Technol. 76, 345-357. 
Miller, G. M. (1959). "Use of dinitrosalicylic acid reagent for determination of reducing sugar," Anal. Chem. 31, 426-428. DOI: 10.1021/ac60147a030

Mooney, C. A., Mansfield, S. D., Touhy, M. G., and Saddler, J. N. (1998). "The effect of initial pore volume and lignin content on the enzymatic hydrolysis of softwoods," Bioresour. Technol. 64, 113-119. DOI: 10.1016/S0960-8524(97)00181-8

Mosier, N., Wyman, C., Dale, B., Elander, R., Lee, Y. Y., Holtzapple, M., and Ladisch, M. (2005). "Features of promising technologies for pretreatment of lignocellulosic biomass," Bioresour. Technol. 96, 673-686. DOI: 10.1016/j.biortech.2004.06.025

Qin, L., Li, W. C., Zhu, J. Q., Liang, J. N., Li, B. Z., and Yuan, Y. J. (2015). "Ethylenediamine pretreatment changes cellulose allomorph and lignin structure of lignocellulose at ambient pressure," Biotechnol. Biofuels. 8, 174. DOI: $10.1186 / \mathrm{s} 13068-015-0359-\mathrm{z}$

Sánchez, O. J., and Cardona, C. A. (2008). "Trends in biotechnological production of fuel ethanol from different feedstocks," Bioresour. Technol. 99, 5270-5295. DOI: 10.1016/j.biortech.2007.11.013

Selig, M.J., Viamajala, S., Decker, S.R., Tucker, M.P., Himmel, M.E., and Vinzant, T.B. (2007). "Deposition of lignin droplets produced during dilute acid pretreatment of maize stems retards enzymatic hydrolysis of cellulose," Biotechnol. Prog. 23, 13331339.DOI: $10.1021 / \mathrm{bp} 0702018$

Singh, J., Suhag, M., and Dhaka, A. (2015). “Augmented digestion of lignocellulose by steam explosion, acid and alkaline pretreatment methods: A review," Carbohyd. Polym. 117, 624-631. DOI: 10.1016/j.carbpol.2014.10.012

Singh, R., Shukla, A., Tiwari, S., and Srivastava, M. (2014). "A review on delignification of lignocellulosic biomass for enhancement of ethanol production potential," Renew. Sustain. Energ. Rev. 32, 713-728. DOI: 10.1016/j.rser.2014.01.051

Sun, Y., and Cheng, J. (2002). "Hydrolysis of lignocellulosic materials for ethanol production: a review," Bioresour. Technol. 83, 1-11. DOI: 10.1016/S09608524(01)00212-7

Toquero, C., and Bolado, S. (2014). "Effect of four pretreatments on enzymatic hydrolysis and ethanol fermentation of wheat straw. Influence of inhibitors and washing," Bioresour. Technol. 157, 68-76. DOI: 10.1016/j.biortech.2014.01.090

Van Soest, P. J., Rovertson, J. B., and Lewis, B. A. (1991). "Methods for dietary fiber, neutral detergent fiber, and nonstarch polysaccharides in relation to animal nutrition," J. Dairy Sci. 74, 3583-3597. DOI: 10.3168/jds.S0022-0302(91)78551-2

Viola, A. E., Zimbardi, A. F., Cardinale, A. M., Cardinale, A. G., Braccio, A. G., and Gambacorta, E. (2008). "Processing cereal straws by steam explosion in a pilot plant to enhance digestibility in ruminants," Bioresour. Technol. 99, 681-689. DOI: 10.1016/j.biortech.2007.02.001

Wang, W., Zhu, Y., Du, J., Yang, Y., and Jin, Y. (2015a). "Influence of lignin addition on the enzymatic digestibility of pretreated lignocellulosic biomasses," Bioresour. Technol. 181, 7-12. DOI: 10.1016/j.biortech.2015.01.026

Wang, P., Chang, J., Yin, Q. Q., Wang, E. Z., Zhu, Q., Song, A. D., and Lu, F. S. (2015b). "Effects of thermo-chemical pretreatment plus microbial fermentation and enzymatic hydrolysis on saccharification and lignocellulose degradation of corn straw," Bioresour. Technol. 194, 165-171. DOI: 10.1016/j.biortech.2015.07.012

Wang, E. Z. (2015c). Study on the combined physicochemical pretreatments and enzymatic hydrolysis for transferring corn straw to chicken feedstuff resources. Master's Thesis, Henan Agricultural University, Zhengzhou, China. 
Yu, H. B., Zhang, X. Y., Ke, J., and Ma, F. Y. (2009). "Optimization of enzymatic hydrolysis of corn straw after biological-alkaline/oxidative pretreatment," Transactions CSAE 25, 201-205.

Yun, L. (2014). "Dynamics of water suction of corn stalks in alkali treatment and its relationships with physicochemical indexes," J. Ecol. Rural Environ. 30, 398-402.

Zhang, Z. C., Xia, L. L., Wang, F., Lv, P., Zhu, M. X. Q., Li, J. H., and Chen, K. P. (2015). "Lignin degradation in corn stalk by combined method of $\mathrm{H}_{2} \mathrm{O}_{2}$ hydrolysis and Aspergillus oryzae GMCC5992 liquid-state fermentation," Biotechnol. Biofuels. 8, 183. DOI: 10.1186/s13068-015-0362-4

Article submitted: June 6, 2017; Peer review completed: July 24, 2017; Revised version received: July 31, 2017; Accepted: August 1, 2017; Published: August 4, 2017.

DOI: 10.15376/biores.12.4.7002-7015 